\title{
REVIEW
}

\section{BRITAIN AND EUROPE AT A CROSSROADS. THE POLITICS OF ANXIETY AND \\ TRANSFORMATION, BY ANDREW RYDER (BRISTOL UNIVERSITY PRESS, 2020)}

PÉTER FUTÓ ${ }^{1}$

This is an interesting and coherent book which offers a specific interpretation of Brexit by examining the political discourse and investigating its linguistic and rhetoric context. The author applies the method of critical discourse analysis, which links the micro analysis of speech acts (speeches, public statements, political adverts, and interviews) with a macro approach that critically assesses the relationship between speech acts and the historical and socio-economic profile of Britain. The Brexit debate is used as a case study to demonstrate that power is embodied in discourse and knowledge, and that sophisticated verbal constructs are capable of manipulating a range of dispositions, emotions, and identities to the extreme.

Andrew Ryder's previous work has focused on a range of challenges facing Roma in British and European societies in the context of the policy areas of integration, health, social policy, employment, and education. His previous research on Gypsies and Travellers, as well as this book on Brexit, serve as case studies of how power, control, and justice function in a renewed public sphere, in which authoritarian elites bolster their power by generating discord and binary 'us-and-them' agendas.

The book covers both the "Brexit message" and the media that successfully conveyed the latter to the public. The evolution of Brexit nationalism is analyzed as a paradigm shift brought forth partly by contemporary British history, but currently also caused to a great extent by sophisticated ideological manipulation. Special attention is paid to speech acts that serve the rhetoric

1 Dr Péter Futó is an affiliated professor at the Corvinus University of Budapest and works as a freelance consultant. He teaches and does research and consultancy work in Entrepreneurial Economics, Environmental Economics, Local Development, and Regulatory Impact Assessment, e-mail: peter.futo@uni-corvinus.hu. 
of "securitization," which is a process of transforming policy subjects into matters of security. In the specific case of the Brexit debate, securitization consists of exaggerating the risks...

- of immigration,

- of the danger of parliamentary democracy being undermined, and

- of the handing over of control to the EU (loss of sovereignty).

The analysis shows how various political actors attempted to generate moral panic in the British public. The author identifies the social movements, organizations, parties and influential actors who overtly or subtly manipulated the public by framing the Brexit debate as an issue of identity and nationhood using populistic arguments and speech acts. The book tests the hypothesis that the Brexit debate lacks a coherent framework, and highlights the underlying economic, historical, social, cultural and political mechanisms of how the shift towards this irrational framing happened. While chronicling the process of Brexit, the author demonstrates how the debate has undermined democracy, and the public's attachment to it.

The substantive part of the analysis deals with the Brexit strategies of the Conservatives, of Labour, and of the Nationalists (the UK Independence Party/ Brexit Party, and the Scottish Nationalists), analyzing their strategies and highlighting the complexity and incoherence of their respective rhetorics. It is shown that, in interpreting Brexit policies, a wide range of game theory concepts such as bluff, bravado, and simulated irrationality are relevant elements. In particular, the book demonstrates...

- how the privileges of self-interested elites have been portrayed in the Brexit debate by demagogues as the "will of the people;"

- how antagonistic radicalisms trivialized the political debate by converting respected adversaries into enemies, thereby preventing deliberation and the development of moral consensus, and depriving citizens of choices based on meaningful and feasible compromises;

- to what extent reactive forms of identity, conservatism, and nativism have proved to be fertile ground for the politics of nationalist populism;

- and finally, how a populist goal has been achieved within a political system based on representative democracy by using a sophisticated toolkit of populist campaign tactics, such as surveys, social media, tabloids, technology, and the professional application of the science of marketing.

A recurrent topic of the book is populism and its symptoms, instruments, and representatives. The analysis points out the parallels between various analogous instances of moral panic in Britain. 
The author demonstrates the parallels between...

- the Brexit debate on the one hand,

- and the demonization of Gypsies before and during the 2005 election on the other hand.

The latter hysteria was orchestrated by certain conservative newspapers and party leaders in the run up to the 2005 General Election. The demagoguery and the subsequently generated moral panic was witnessed first-hand by the author, who at that time was working as an activist for a campaign alliance of Gypsies and Travellers in the UK. The author feels that the use of race by leading political figures in a national poll was a turning point, as the Conservatives at a national level seemed to admit and apply certain elements of racist argumentation to obtain votes - a development that presaged the manipulation of the Brexit referendum and discourse.

In the case of the Brexit debate, it was migrants who were used by populists as scapegoats and "folk devils," with the aim of fomenting a previously unknown form of nationalism, which the author calls "Brexit nationalism."

In both cases, the divisive campaign topoi (i.e. "lines of argument," or "commonplaces") were similar, but gradually became more sophisticated. The book argues that controversial strategies for winning elections and referenda were used then, and since have been consciously and intentionally applied. Regarding the issues of race, identity, and migration, populist propaganda has frequently disregarded the truth and launched crude and simplistic slogans. This has revived various concerns and emotions and aroused a level of public anxiety formerly unknown by this generation.

The closing chapter provides an outlook on the expected social, political, and economic impacts of Brexit on the economy, on migration, on social cohesion and tensions, and on elite-driven authoritarian populism. The author recommends developing deliberative democracy based on institutionalized reciprocities, and on informed, collective conversation and decision-making. The deliberative approach can lead to a radical new consensus and to a transformative change which would be a more effective remedy for the current ills of the political system. In particular, and on a personal note, the author remains confident that one day Britain will rejoin the EU.

This book is essential reading for researchers and students interested in British politics, but also for those who wish to gain insight into the nature of populism and the manipulation of the public sphere in times of anxiety. 
